<巻 頭 随 想 $>$

\title{
健康で豊かな食を支える発酵食品の 新展開に期待
}

（独）農研機構 理事 食品総合研究所 所長

ワイン, ビール，日本酒等のアルコール飲料をはじめ, 東南アジアの魚奨, 中東のヨーグルト, 欧 米のパン，チーズ等は，いずれも微生物を利用した発酵食品である。醗酵食品は有史以前からの長 い歴史があり，最古の醗酵食品は 8 千年前のコーカサス地方のワインであり，イランでも 7 千年前 にワインを醸造していたことが確認されている。

これらの発酵食品は，微生物という正体が明らかにされる以前より製造されてきた。微生物，発 酵温度，雑菌防止といった知識はもとより，文字もなく，発酵する容器すら十分に手に入らない太古 より，経験を頼りに製造されてきた。また，糖からアルコールが生成するように，発酵により素材成 分とは全く異なる成分が生成するのみならず，極めて特徵的な風味が付与されるため，発酵食品は 原料・素材とは全く異なる食品であるといっても過言ではない。

海外出張で長期間，日本から離れると「寿司」(酢を使用)，「味増汁」がむしょうに恋しくなるよ うに，発酵食品は我々の食文化と切り離せない存在である。これは日本人ばかりでなく，他民族に おいても同様であり, フランス人はワイン，チーズが，東南アジア人は料理の味付けに必須の魚酱 油が恋しくなる。いわば，地域の気候風土に根ざした発酵食品が，その地域特有の食文化を形成し ているといっても過言ではなく，発酵食品は食文化のかなめであり地域の食を豊かに特徵づけてい る。

さらに，赤ワインに含まれる「レスベラトロール」は抗ガンやアンチエイジング効果が，味噌に含 まる「脂肪酸エチル」は抗ガン作用があるといわれている。大半の発酵食品には健康機能に寄与す る有用成分が含まれており，特定保健用食品の認定を受けている発酵食品もある。また，こうした 特定の成分ばかりでなく，発酵食品はトータルとしての食の健全性にも大きく寄与している。日本型 食生活は，炭水化物・タンパク質・脂質の摂取エネルギー比が理想レベルに近く，我が国の長寿を 支えているが，この日本型食生活になくてはならないものが，味増，奨油，納豆等の発酵食品である。

我が国の発酵食品に不可欠な微生物が麹菌であり，そのゲノムは 5 年前に解読され，約 12,000 の 遺伝子を有し, 微生物の中では最大級であり加水分解酵素遺伝子やアミノ酸や脂質の合成・分解な どに関わる遺伝子を多く持つことが明らかにされた。微生物には「眠った状態の遺伝子」，すなわち 「休眠遺伝子」が予想をはるかに越えて多数存在することが分かっている。大半の遺伝子が未利用 のまま「宝の山」として残されており，こうした休眠遺伝子を覚醒する手法も見出され，放線菌では 新規構造の抗生物質生産に成功している。麦匊菌ゲノムで明らかにされた遺伝子情報を基に，休眠遺

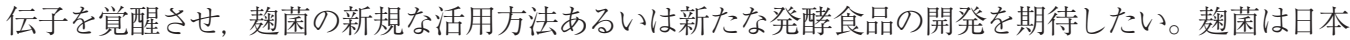
人の食生活に深く関わってきた微生物で「国菌」とも呼ばれており，有史以前より突然変異等によ り生じた優れた特性を蓄積している他，その安全性は広く世界で認められている。ゲノム情報の活 用により「国菌」の新たな展望が開け，5兆円ともいわれている麹菌関連産業の活性化に大いに寄 与することを期待したい。 